Article

\title{
Evolutionary Divergence of Duplicate Copies of the Growth Hormone Gene in Suckers (Actinopterygii: Catostomidae)
}

\author{
Henry L. Bart Jr. *, Paulette C. Reneau, Michael H. Doosey ${ }^{\dagger}$ and Charles D. Bell ${ }^{\ddagger}$ \\ Department of Ecology and Evolutionary Biology, Tulane University, New Orleans, LA 70118, USA; \\ E-Mails: preneau@tulane.edu (P.C.R.); mdoosey@tulane.edu (M.H.D.); cdbell1@uno.edu (C.D.B.) \\ $\dagger$ Current Address: Natural History Museum and Biodiversity Research Center, University of Kansas, \\ Lawrence, KS 66045, USA \\ * Current Address: Department of Biological Sciences, University of New Orleans, New Orleans, LA \\ 70148, USA
}

* Author to whom correspondence should be addressed; E-Mail: hank@museum.tulane.edu; Tel.: +1 504 8628283; Fax: +1 5048628706 .

Received: 9 January 2010; in revised form: 1 March 2010 / Accepted: 3 March 2010 / Published: 16 March 2010

\begin{abstract}
Catostomid fishes (suckers) have duplicate copies of the growth hormone gene and other nuclear genes, due to a genome duplication event early in the group's history. Yet, paralogs of GH in suckers are more than $90 \%$ conserved in nucleotide (nt) and amino acid (aa) sequence. Within paralogs across species, variation in nt and aa sequence averages $3.33 \%$ and $4.46 \%$ for GHI, and $3.22 \%$ and $2.43 \%$ for GHII, respectively. Selection tests suggest that the two GH paralogs are under strong purifying selection. Consensus trees from phylogenetic analysis of GH coding region data for 23 species of suckers, other cypriniform fishes and outgroups resolved cypriniform relationships and relationships among GHI sequences of suckers more or less consistently with analyses based on other molecular data. However, the analysis failed to resolve all sucker GHI and GHII sequences as monophyletic sister groups. This unexpected topology did not differ significantly from topologies constrained to make all GH sequences monophyletic. We attribute this result either to limitations in our GHII data set or convergent adaptive changes in GHII of tribe Catostomini.
\end{abstract}

Keywords: cypriniformes; nuclear gene; paralog; parsimony analysis 


\section{Introduction}

Genome duplication has long been thought to play an important role in evolution, giving rise to duplicate copies of genes (paralogs) which subsequently diverge and assume other functions [1,2]. Recent work has highlighted three episodes of genome duplication in vertebrates, which have been linked to the diversification of vertebrates, gnathostomes and teleosts, respectively [3-6]. The three duplication events coincide with bursts of character acquisition and increases in phenotypic complexity in living species, which many researchers attribute to functional divergence of duplicate genes [4]. However, mechanisms of functional divergence are difficult to establish over such long periods of evolutionary time.

Growth hormone $(\mathrm{GH})$ is a single-chain, pituitary-specific hormone essential for promotion and maintenance of somatic growth in vertebrates [7-9]. The GH genomic region in vertebrates is roughly $2 \mathrm{~kb}$ long, with the protein coding region divided into four to five blocks (exons) representing less than a third of the length of the genomic region. The GH coding region tends to be highly conserved across vertebrates, presumably because of functional constraints on structure of the hormone. However, rates of GH sequence evolution vary for other groups of vertebrates. GH paralogs in passerine birds were shown to exhibit rapid evolution compared to non-passerines [10]. Comparison of substitution rates in these two groups indicated a 2-fold faster rate of synonymous codon evolution and a 10-fold greater rate of amino acid evolution in passerine birds than in non-passerines. Variability in the rate of evolution of pituitary GH has also been detected in mammals [11]. Whereas GH is highly conserved across most eutherian orders, the gene exhibits $25-50$ fold higher rates of evolution in primates and artiodactyls.

Sequences from the GH gene region have been used to infer evolutionary relationships at a variety of taxonomic levels in fishes. GH coding sequences were used to resolve phylogenetic relationships of major clades of fishes [12-16]. Amino acid (aa) sequences from the protein-coding region of GH were first used for inferring the phylogeny of "bony" fishes by Bernardi et al. [17]. Interrelationships of major groups of fishes based on GH coding and aa sequences are generally in agreement with relationships based on morphology and other data [12,13,16-19].

$\mathrm{GH}$ intron sequences have been used to infer sub-familial phylogenetic relationships of salmonids [20] and labeonines of family Cyprinidae [21], and to characterize intraspecific, population genetic structures of various groups of fishes $[8,18,22,23]$. GH coding region sequences are being used as part of a multi-gene study of phylogenetic relationships of fishes of Order Cypriniformes [24].

Like salmonids, cypriniform fishes of Family Catostomidae and certain groups of Family Cyprinidae are tetraploids, believed to have arisen due to a hybridization event early in the history of these groups [25]. However, this hypothesis was not tested in an explicitly phylogenetic context, until recently. Work on the GH gene in the catostomid, Ictiobus bubalus, has revealed that GH duplication in catostomids was independent of the duplication event that gave rise to paralogous copies of GH in cyprinids [16]. Catostomids are the oldest known cypriniform fishes with fossils dating back to the lower Paleocene, suggesting that the minimum age for the divergence of catostomid species and paralogs of $\mathrm{GH}$ is 60 million years.

In this study, we describe genomic organization and size variation of duplicate copies of the GH gene in catostomid fishes. We use GH coding region sequences to infer phylogenetic relationships of 
paralogous copies of the gene in suckers and other cypriniform fishes. We also use GH coding DNA to infer variation in amino acid composition and structure of the GH protein.

\section{Results and Discussion}

\subsection{Sequences of Catostomid GH}

Partial to complete sequences of two distinct copies of GH were determined for 14 catostomid species; complete sequences for one of the GH copies were obtained from nine additional species (Table 1). BLAST searches of the coding regions revealed high similarity of the new GH sequences with GH copies of Ictiobus bubalus and other cypriniform fishes. The two GH copies are named GHI and GHII based on their sequence homology with GH copies in I. bubalus [16].

We were able to produce complete coding region data for GHI for most catostomid species using methods described in the experimental section. We were able to produce data for the 5' end of GHII (Exons 2 and 3) for most catostomid species using GHII specific primers developed in a previous study [16]. However, despite several attempts involving a number of different techniques (also described in the experimental section), thus far we have only been able to produce data for the 3' end of GHII for species representing tribes Erimyzonini and Catostomini of subfamily Catostominae, in addition to a previously published GHII sequence for I. bubalus of subfamily Ictiobinae [16].

The genomic organization of GH in suckers is the same as in other Cypriniformes [26,27]. The complete GH genomic sequence comprises five exons and four introns with a total length of 1,500-2,700 nt depending on lengths of the four introns. Exons of different sucker species are of fixed lengths as follows: 10 (Exon 1), 140 (Exon 2), 117 (Exon 3), 162 (Exon 4), and 204 (Exon 5) nt. Introns vary in size across species, from 155-269 (Intron 1), 154-215 (Intron 2), 311-1,188 (Intron 3), and 102-154 (Intron 4) nt (Table 2). The GHII genomic sequence is shorter than that of GHI, with much of the difference due to the substantially longer $3^{\text {rd }}$ intron of GHI.

The GH coding region of catostomids is $633 \mathrm{nt}$ in length. The predicted amino acid (aa) sequences of GHI and GHII encode a protein of 210 aa, which is identical to the protein size reported for other cypriniforms [16,22,28]. The putative GH signal peptide cleavage site is serine at aa position 23, which gives a predicted mature polypeptide size of 188 aa, consistent with other cypriniform species [28].

The two GH copies are very similar in both nt and aa sequence composition. Mean nt divergence between GHI and GHII is $9.61 \%$. Mean pairwise aa sequence divergence between copies is $8.53 \%$. Mean pairwise nt sequence divergence within paralogs (coding region data only) across catostomid species is $3.33 \%$ for GHI and $3.22 \%$ for GHII. Mean aa divergence within paralogs is $4.46 \%$ for GHI and $2.43 \%$ for GHII. The lower percentage in aa divergence for GHII is due to the incomplete data for several of the catostomine species.

An interesting and potentially evolutionarily significant difference in GH copies of suckers involves variation in the number of cysteine residues in the mature peptide. Pairs of cysteine residues form disulfide bonds, important to protein folding and stability [29]. GH in all vertebrates has four cysteine residues in highly conserved positions in the amino acid sequence. Ostariophysan fishes have an unpaired, fifth cysteine in aa position 145. In GHI of catostomids, the extra cysteine is replaced by tyrosine. The functional significance of this disparity has yet to be established. 
Table 1. List of species used in the comparative and phylogenetic analysis of catostomid GH sequences.

\begin{tabular}{|c|c|c|c|}
\hline Species & Copy & Source & GenBank number \\
\hline Carpiodes cyprinus & $\mathrm{I}$ & this study & GU937834 \\
\hline Carpiodes sp. cf. cyprinus & $\mathrm{I}$ & this study & GU937849 \\
\hline Catostomus catostomus & I & this study & GU937824 \\
\hline C. catostomus & II & this study & GU937826 \\
\hline C. commersonii & $\mathrm{I}$ & Mayden et al. 2009 & FJ265027 \\
\hline C. commersonii & II & this study & GU937823 \\
\hline C. discobolus & $\mathrm{I}$ & this study & GU937830 \\
\hline C. discobolus & II & this study & GU937832 \\
\hline C. plebeius & $\mathrm{I}$ & this study & GU937833 \\
\hline C. plebeius & II & this study & GU937829 \\
\hline Chasmistes brevirostris & $\mathrm{I}$ & this study & GU937825 \\
\hline C. brevirostris & II & this study & GU937827 \\
\hline Cycleptus elongatus & $\mathrm{I}$ & Mayden et al. 2009 & FJ265028 \\
\hline Deltistes luxatus & $\mathrm{I}$ & this study & GU937831 \\
\hline D. luxatus & II & this study & GU937828 \\
\hline Erimyzon oblongus & $\mathrm{I}$ & this study & GU937837 \\
\hline E. oblongus & II & this study & GU945705 \\
\hline E. tenuis & $\mathrm{I}$ & this study & GU937838 \\
\hline E. tenuis & II & this study & GU937839 \\
\hline Hypentelium etowanum & $\mathrm{I}$ & this study & GU937836 \\
\hline H. nigricans & I & Mayden et al. 2009 & FJ265055 \\
\hline Ictiobus bubalus & $\mathrm{I}$ & Clements et al. 2004 & AY375301 \\
\hline I. bubalus & II & Clements et al. 2004 & AY375302 \\
\hline I. cyprinellus & $\mathrm{I}$ & this study & GU937840 \\
\hline Minytrema melanops & $\mathrm{I}$ & Mayden et al. 2009 & FJ265050 \\
\hline M. melanops & II & this study & GU937822 \\
\hline Moxostoma austrinum & $\mathrm{I}$ & this study & GU937841 \\
\hline M. breviceps & $\mathrm{I}$ & this study & GU937842 \\
\hline M. carinatum & $\mathrm{I}$ & this study & GU937843 \\
\hline M. carinatum & II & this study & GU937835 \\
\hline M. cervinum & $\mathrm{I}$ & this study & GU937844 \\
\hline M. cervinum & II & this study & GU937845 \\
\hline Myxocyprinus asiaticus & $\mathrm{I}$ & Mayden et al. 2009 & FJ265052 \\
\hline Thoburnia atripinnis & $\mathrm{I}$ & this study & GU937846 \\
\hline T. rhothoeca & $\mathrm{I}$ & this study & GU937847 \\
\hline T. rhothoeca & II & this study & GU937848 \\
\hline Acheilognathus typus & & Mayden et al. 2009 & FJ265056 \\
\hline Carassius auratus & $\mathrm{I}$ & Law et al. 1996 & AF069398 \\
\hline C. auratus & II & Law et al. 1996 & AF069399 \\
\hline C. a. gibelio & & unpublished & AY265352 \\
\hline Clarius batrachus & & unpublished & AF416485 \\
\hline Cyprinella lutrensis & & Mayden et al. 2009 & FJ265061 \\
\hline
\end{tabular}


Table 1. Cont.

\begin{tabular}{lclc}
\hline \multicolumn{1}{c}{ Species } & Copy & \multicolumn{1}{c}{ Source } & GenBank number \\
\hline Cyprinus carpio & I a & Mayden et al. 2009 & FJ265047 \\
C. carpio & I b & unpublished & AJ640136 \\
C. carpio & II & unpublished & AJ640135 \\
Gyrinocheilus aymonieri & & Mayden et al. 2009 & FJ265031 \\
Hemibarbus barbus & & Mayden et al. 2009 & FJ265032 \\
Heteropneustus fossilis & & unpublished & AF416489 \\
Homaloptera leonardi & & Mayden et al. 2009 & FJ265022 \\
Labeo senegalensis & & Mayden et al. 2009 & FJ265034 \\
Lefua echigonia & Mayden et al. 2009 & FJ265023 \\
Leptobotia mantschurica & & Mayden et al. 2009 & FJ265035 \\
\hline
\end{tabular}

\subsection{Phylogenetic Analysis of GHI and GHII}

The consensus trees obtained with MP and ML analyses are identical. Only the MP tree is shown (Figure 1). The MP analysis is based on 230 parsimony informative sites in the combined GHI/GHII data set (300 sites are constant). The MP consensus tree is 726 steps long. Order Cypriniformes (Node 1 in Figure 1) is recovered as a monophyletic group with strong bootstrap support. Gyrinocheilus aymonieri (Family Gyrinocheilidae) is strongly supported as the most basal cypriniform. Thus, GH data does not support a monophyletic Superfamily Cobitoidea inclusive of gyrinocheilids, loaches and catostomids, as supported by morphology [30,31] and analysis of multiple nuclear genes and mitogenome data [24].

Two strongly supported interfamilial groups make up the strongly supported sister group to Gyrinocheilus aymonieri. The first of these groups (Node 2) comprises a strongly supported family Cyprinidae (Node 3), sister to a strongly supported group of GHII sequences for representatives of tribe Catostomini (Node 4). The second group (Node 5) comprises a strongly supported basal group of cobitids and balitorids (Node 6), sister to a strongly supported group of GHI and GHII sequences representing other subfamilies and tribes of family Catostomidae (Node 7).

Family Cyprinidae comprises strongly supported subfamily groups of Cyprinines, and Leuciscines plus Gobionines. Within subfamily Cyprininae, the two copies of GH in tribe Cyprinini form a strongly supported monophyletic group, with sequences for each of the copies forming strongly supported monophyletic sister groups.

Five nt substitutions link cyprinid GH sequences with GHII sequences of suckers representing tribe Catostomini, thus rendering the two copies of GH in suckers, and catostomids as a whole, non monophyletic. In contrast, the GHI portion of the tree is well-resolved, monophyletic, and more or less consistent with hypotheses of catostomid relationships based on other data [32,33]. GHI of Myxocyprinus asiaticus is most basal. This species is sister to a strongly supported group comprising a monophyletic Catostominae GHI plus a strongly supported group of Cycleptus elongatus plus a monophyletic subfamily Ictiobinae GHI, the latter group comprising a monophyletic Carpiodes plus a monophyletic Ictiobus. The catostomid GHI tree is the strongly supported sister group to GHII sequences for the remaining catostomid species. In the latter group, Ictiobus bubalus GHII is basal and sister to a strongly supported group comprising GHII sequences for species representing tribes Erimyzonini, Moxostomatini and Thoburniini of subfamily Catostominae. 
Figure 1. Majority rule consensus tree of 2000 bootstrap replicates from maximum parsimony analysis of cypriniform GH sequence data. Filled circles at nodes represent bootstrap support greater than $95 \%$.

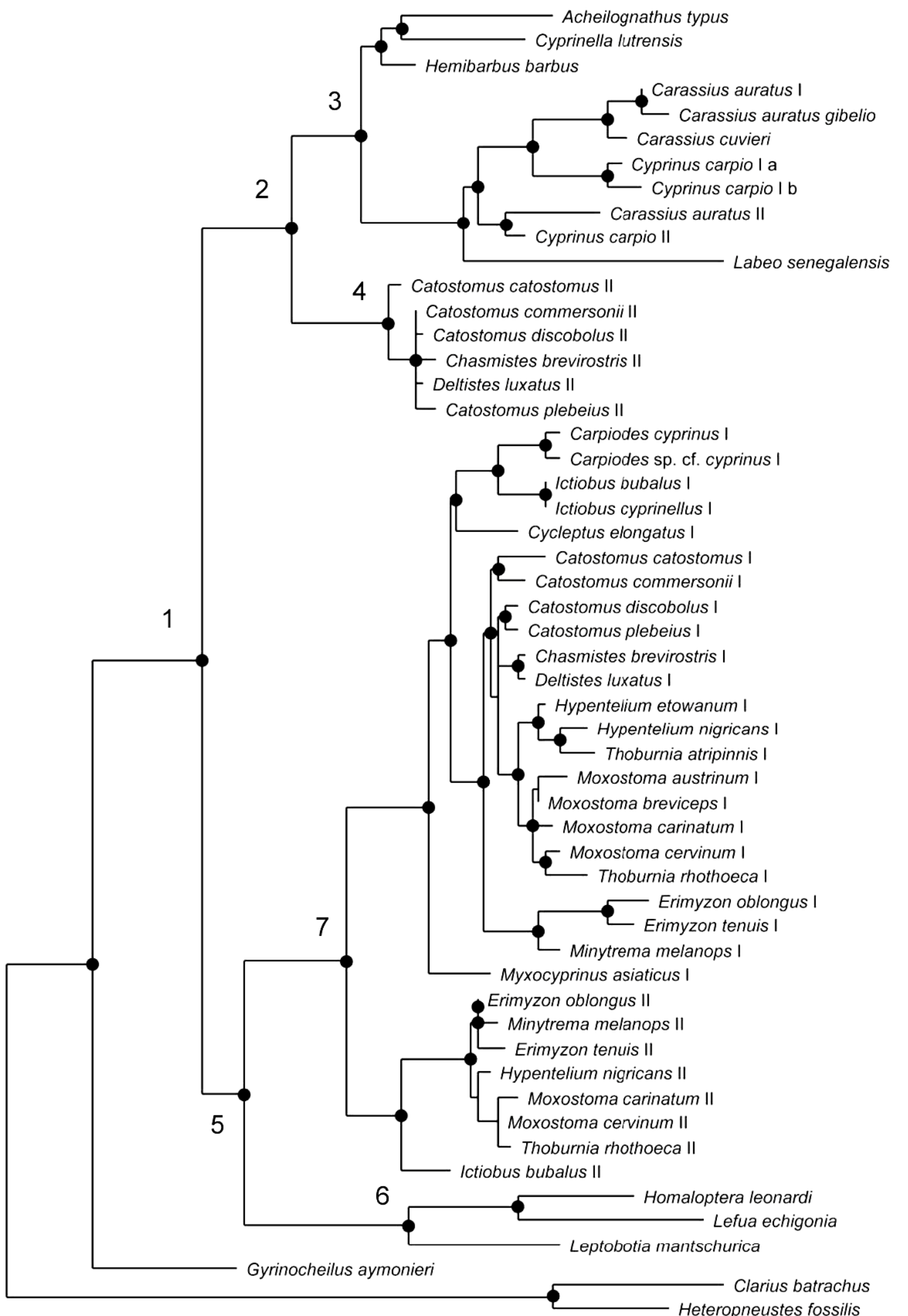


Table 2. Genomic organization of GH gene in suckers includes length of UTRs, introns, GH fragment sequenced (Gene), and coding sequence (CDS). Museum vouchers are included when available.

\begin{tabular}{|c|c|c|c|c|c|c|c|c|c|c|}
\hline Species & Copy & Voucher & 5' UTR & Intron 1 & Intron 2 & Intron 3 & Intron 4 & 3' UTR & Gene & CDS \\
\hline Carpiodes cyprinus & I & None & & na & na & na & na & & & 607 \\
\hline Carpiodes sp. cf. cyprinus & I & None & & & 207 & 985 & 154 & & 1878 & 532 \\
\hline Catostomus catostomus & I & UAIC 11218.05 & & 228 & 194 & 949 & 154 & & 2117 & 550 \\
\hline C. catostomus & II & UAIC 11218.05 & 39 & 174 & 194 & 311 & 145 & & 1470 & 607 \\
\hline C. commersonii & I & None & 47 & 235 & 175 & 592 & 102 & & 1788 & 633 \\
\hline C. commersonii & II & None & 31 & 222 & 194 & 311 & 145 & & 1513 & 610 \\
\hline C. discobolus & I & BYU 57986 & 36 & 235 & 198 & 599 & 102 & & 1711 & 541 \\
\hline C. discobolus & II & BYU 57986 & 48 & 220 & 194 & 311 & 142 & & 1531 & 613 \\
\hline C. plebeius & I & MSB 49632 & & 235 & 198 & 599 & 102 & & 1683 & 542 \\
\hline C. plebeius & II & MSB 49632 & & 220 & 194 & 311 & 145 & & 1512 & 603 \\
\hline Chasmistes brevirostris & I & OS 15963 & 35 & 235 & 198 & 596 & 102 & & 2037 & 633 \\
\hline C. brevirostris & II & OS 15963 & & 210 & 194 & 311 & 145 & & 1492 & 593 \\
\hline Cycleptus elongates & I & TU 192331 & & 242 & 203 & 965 & 143 & & 2125 & 571 \\
\hline Deltistes luxatus & I & OS 15922 & 35 & 236 & 198 & 596 & 102 & & 1925 & 633 \\
\hline D. luxatus & II & OS 15922 & & 210 & 194 & 311 & 145 & & 1517 & 611 \\
\hline Erimyzon oblongus & I & NCSM 37439 & & & 185 & 955 & 154 & & 1845 & 543 \\
\hline E. oblongus & II & NCSM 37439 & 557 & 227 & 199 & & & & 1157 & 150 \\
\hline E. tenuis & I & None & 259 & 259 & 192 & 947 & 154 & & 2395 & 633 \\
\hline E. tenuis & II & None & 139 & 225 & 199 & & & & 826 & 263 \\
\hline Hypentelium etowanum & I & None & 176 & 248 & 197 & 832 & 146 & & 2293 & 633 \\
\hline H.nigricans & I & None & 147 & 252 & 197 & 901 & 146 & & 2212 & 569 \\
\hline H. nigricans & II & None & 639 & 226 & 181 & & & & 1287 & 225 \\
\hline Ictiobus bubalus & I & TU 196158 & 56 & $\mathrm{Na}$ & na & na & na & 590 & & 633 \\
\hline I.bubalus & II & TU 196158 & 56 & $\mathrm{Na}$ & na & na & na & 590 & & 633 \\
\hline I. cyprinellus & I & None & & & 204 & 870 & 154 & & 1787 & 559 \\
\hline Minytrema melanops & I & TU 193988 & 147 & 254 & 193 & 1188 & 154 & & 2569 & 633 \\
\hline M. melanops & II & TU 193988 & 627 & 225 & 182 & $320^{\mathrm{a}}$ & 154 & & $2141^{\mathrm{a}}$ & 633 \\
\hline Moxostoma austrinus & I & None & & 261 & 200 & 914 & 143 & & 2074 & 548 \\
\hline M. breviceps & I & None & 38 & 225 & 200 & 936 & 143 & & 2084 & 542 \\
\hline M. carinatum & I & None & 211 & 259 & 200 & 936 & 143 & & 2392 & 633 \\
\hline M. carinatum & II & None & & 225 & 179 & & & & & 150 \\
\hline M. cervinum & I & None & & 263 & 200 & 928 & 143 & & 2092 & 542 \\
\hline M. cervinum & II & None & 618 & 224 & 181 & & & & & 267 \\
\hline Myxocyprinus asiaticus & I & None & 31 & 269 & 215 & 969 & 154 & & 2180 & 541 \\
\hline Thoburnia atripinnis & I & None & 211 & 252 & 195 & 936 & 152 & & 2442 & 633 \\
\hline T. rhothoeca & I & None & 208 & 252 & 199 & 914 & 146 & 64 & 2416 & 633 \\
\hline T. rhothoeca & II & None & 638 & 224 & 154 & & & & & 267 \\
\hline
\end{tabular}

The sister group relationship of Catostomini GHII sequences with cyprinids was unexpected. Of the five nt substitutions inferred along this branch, four are not shared with other catostomid $\mathrm{GH}$ sequences, and two of these substitutions result in aa changes that are also not shared with other catostomids (valine to methionine at aa position 90 and leucine to methionine at aa position 169). The 
two aa substitutions are in C-terminal end of the protein, corresponding to Exons 4 and 5. GHII data from this end of the gene is available only for Minytrema melanops among Tribes Erimyzonini, Moxostomatini and Thoburniini. GHII sequences of Tribe Catostomini share nine nt characters with GHI and/or GHII sequences from other catostomids and would likely share more if GHII data were more complete. Two of the nine substitutions result in aa changes that are convergent with aa character states in other catostomid GH sequences (serine to cysteine in aa position 14 [signal peptide] and glycine to aspartic acid in aa position 81). It is possible that missing GHII data from the 3' end of the gene, especially for other tribes of catostomines, would have supported a different tree topology.

When all catostomid GHII sequences are constrained to be monophyletic, the resulting tree is 11 steps longer than the MP consensus tree. When Catostomini GHII sequences are constrained to be the sister group of catostomid GHI plus the remaining GHII sequences, the resulting tree is only four steps longer than the MP consensus tree. Based on Templeton test results, neither constraint tree is significantly longer than the MP consensus tree (GHII monophyletic: $Z=-1.9149, p=0.0555$; Catostomini GHII sister to remaining catostomid GHI and GHII sequences: $Z=-0.8944, p=0.5034$ ).

\subsection{Selection Tests}

We compared coding sequences of the mature GHI and GHII proteins of catostomids to gain insight into the possible evolutionary forces affecting the divergence of the two copies of the hormone. The comparison revealed a lower number of non-synonymous differences per non-synonymous site $\left(d_{\mathrm{N}}\right)$ relative to the number of synonymous differences per synonymous site $\left(d_{\mathrm{S}}\right)(P=0.003$, Z-test of positive selection), indicating a paucity of amino acid replacement changes compared with neutral expectations. Thus, the null hypothesis of strict neutrality $\left(d_{\mathrm{N}}=d_{\mathrm{S}}\right)$ can be rejected in favor of the alternative hypothesis of purifying selection $\left(d_{\mathrm{N}}<d_{\mathrm{S}}\right)$ for all catostomid species. Purifying selection is also suggested for pairwise comparisons of GHI and GHII of the cyprinids Carassius auratus and Cyprinus carpio. There is no evidence for positive selection among the GH sequences tested. The slow rate of divergence of the GH coding region observed across suckers and other cypriniforms is not surprising considering the protein's critical role in promoting growth and differentiation at distant target sites [34] as well as its secondary functions in autocrine/paracrine regulation of cellular differentiation during embryonic development [35,36].

\section{Experimental Section}

\subsection{DNA Extraction, PCR, and Sequencing}

Total DNA was extracted from ethanol preserved muscle or fin tissue with the Purelink Genomic DNA Mini Kit (Invitrogen, Carlsbad, CA). PCR amplification was conducted in two steps, long PCR and full-nested short PCR. The long PCR primer pair GH22F (5'-YTGTCKDTGGTSCTGGTYAGT-3') and GHR (5'-CAGGGTRCAGTTKGAATCSAR-3') was used in a 15.5- $\mu \mathrm{L}$ reaction mixture containing $9.725 \mu \mathrm{L}$ sterile water, $1.5 \mu \mathrm{L}$ Ex Taq buffer, $1.2 \mu \mathrm{L}$ dNTPs $(2.5 \mathrm{mM}), 1.0 \mu \mathrm{L}$ each primer $(10 \mu \mathrm{M}), 0.075 \mu \mathrm{L} \mathrm{Taq}$ polymerase (Takara Ex Taq, Takara, Japan), and $1.0 \mu \mathrm{L}$ of template DNA (ca. $50 \mathrm{ng} / \mu \mathrm{L}$ ). The thermal cycle protocol was as follows: (1) initial denaturation at $94{ }^{\circ} \mathrm{C}$ for $60 \mathrm{~s}$; (2) then 30 cycles of denaturation at $94{ }^{\circ} \mathrm{C}$ for $30 \mathrm{~s}$; annealing at $52{ }^{\circ} \mathrm{C}$ for $30 \mathrm{~s}$; and extension at $72{ }^{\circ} \mathrm{C}$ 
for $120 \mathrm{~s}$; and (3) final extension at $72{ }^{\circ} \mathrm{C}$ for $10 \mathrm{~min}$. The first round PCR produced an amplicon ranging from 1,200 to 2,300 bp (depending on length of introns) that spans half of exon 2 to near the termination codon in exon 5. This product contained both GH copies and was cloned in the pGEM-T Easy Vector (Promega, Madison, WI). Positive colonies (i.e. white colonies) were selected and used as a template for short PCR. Short PCR was conducted using up to three internal primer pairs GH22F and GH264R (5'-GCTYTTYTGBGTTTCATSTTT-3'), GH181F (5'-CAGCTGAGTAAAATCTTYCCT-3') and GH295R (5'-CTCCCARGAYTCAATGAGGYG-3'), and GH274F (5'-AAGCTBCTTCGYATCTCYTT-3') and GHR with the same reaction mixtures as above [16,24]. Thermal cycling profile was the same as first round PCR except extension time was reduced to $30 \mathrm{~s}$. Part of the 5' UTR and exons 1 through 3 were amplified and sequenced for catostomids by pairing GH copy specific primers GHIF (5'-AAAGCCTTCAACTAAGACTAAC-3') and GHIIF (5'-CAAACCTTCAACTAAGACTTCA-3'), developed for Ictiobus bubalus [24], with primer GH240R (5'-TTCTGGGTTTCATGTTTGTCA-3'). Short PCR products were purified with ExoSAP-IT (USB, Cleveland, OH) and directly sequenced using BigDye Terminator v3.1 Cycle Sequencing Kits (Applied Biosystems, Carlsbad, CA). The resulting products were analyzed on an ABI 3730xl Genetic Analyzer (Applied Biosystems).

Obtaining complete coding region sequences of GHII for all sucker species proved challenging because we were not able to design internal primers specific to the 3 ' end of this gene copy. We tried designing primers specific to the different sucker tribes and nesting them with our GHII-specific upstream primer and a non-specific downstream primer. This amplified both GH copies. We varied PCR techniques to increase GH yield by performing re-extensions, reconditioning PCR, and varying primer and DNA volumes. This resulted in non-specific primer binding with multiple bands observed during gel electrophoresis. We extended electrophoresis runs on PCR products, cutting out and gel purifying double bands and cloning both products. This yielded large sequences of GHI, but very small fragments of GHII. Lastly, we diluted the ligation mix during cloning in an effort to decrease plasmid incompatibility, thereby increasing the cloning efficiency of paralogous sequences. This method yielded the 3' GHII data for species we have completed thus far.

\subsection{Sequence Alignment, Variation, and Phylogenetic Analysis}

Sequence chromatograms were assembled into contigs and edited with Sequencher 4.6 (Gene Codes, Madison, WI). Inconsistencies in base calls in cloned fragments were infrequent and were resolved by simple majority or left ambiguous. Additional GH sequences were obtained from NCBI by taxonomy and BLASTN searches. Sequences were aligned using CLUSTAL W [37] as implemented in BioEdit [38] and visually inspected for errors and improved manually. Sequence divergence (Tamura-Nei distance), Maximum Likelihood (RAxML [39]) and Maximum Parsimony (PAUP* [40]) analyses were performed on GH coding region data only, using the CIPRES web portal (www.phylo.org). Node support is based on 2,000 bootstrap replicates. The extent of nucleotide sequence divergence was estimated by means of the uncorrected differences ( $p$ distance). Sequence variation was examined by plotting pairwise transitional (TS) and transversional (TV) differences against $p$ distance.

Templeton tests, implemented in PAUP* [40], were conducted to test for differences in the lengths of the MP consensus tree and two alternative topologies constrained as follows: 1) All catostomid 
GHII sequences monophyletic; 2) Catostomini GHII sister to remaining catostomid GHI and GHII sequences.

\subsection{Selection Tests}

The number of synonymous substitutions per synonymous site $\left(d_{\mathrm{S}}\right)$ and nonsynonymous substitutions per nonsynonymous site $\left(d_{\mathrm{N}}\right)$ used in selection tests were estimated using the method of Nei and Gojobori [41] as implemented in MEGA version 4 [42]. Nucleotide and amino acid distances were estimated using a pairwise deletion option for each catostomid species for which complete or partial GHI and GHII sequence were determined. The presence of positive selection was analyzed by testing the null hypothesis that $\mathrm{H}_{o}: d_{\mathrm{N}}=d_{\mathrm{S}}$, versus the alternative positive selection hypothesis that $\mathrm{H} 1$ : $d_{\mathrm{N}}>d_{\mathrm{S}}$ using the codon based z-test for selection [43]. The z-statistic and the probability that the null hypothesis is rejected were obtained as indicated by $\mathrm{P}>0.05$.

\section{Conclusions}

Suckers possess two copies of the growth hormone gene, presumably as a result of a genome duplication event early in the family's history. The two gene copies are remarkably similar in both coding region $\mathrm{nt}$ sequence and aa sequence composition ( $>90 \%$ sequence homology) considering the antiquity of Family Catostomidae. Both GH copies have four cysteine residues in highly conserved positions in the amino acid sequence, which are common to all vertebrates. GHII has a fifth cysteine residue in aa position 145, which is common to all ostariophysan fishes. In GHI of catostomids, the fifth cysteine is replaced by tyrosine. The functional significance of this disparity has yet to be established.

The genomic organization of GH in suckers is the same as in other Cypriniformes, comprising five exons and four introns with a total length of 1,500-2,700 nt, depending on lengths of the four introns. The GHII sequence is shorter than GHI, with much of the difference due to the substantially longer $3^{\text {rd }}$ intron of GHI. An important limitation of this study is that we were only able to produce data for the 5' end of GHII (Exons 2 and 3) for several species representing tribes Erimyzonini and Moxostomatini of Subfamily Catostominae.

The pattern of phylogenetic relationships among cypriniform fishes inferred from coding region sequences of the nuclear GH gene agrees in most respects with relationships inferred from other molecular data. The patterns of relationships among suckers inferred from sequences of GHI and a subset of the GHII sequences are consistent and in basic agreement with relationships based on other data. The only unusual result is the sister relationship between GHII sequences of Tribe Catostomini and cyprinid GH sequences. Although this topology is not significantly different from topologies constrained to make all catostomid GHI and GHII sequences monophyletic, it is the most parsimonious topology and it is supported by uniquely derived nt and aa characters. There are two possible explanations for this result, both requiring additional study: (1) it reflects the effects of incomplete GHII data for a number of catostomine species on character state reconstruction in this portion of the GHII tree; (2) it reflects homoplasy resulting from purifying selection or other functional constraints on GHII evolution. We are gathering the necessary data to address the first of these possibilities before addressing the second. 


\section{Acknowledgements}

This work was supported by NSF grants DEB 0212991 (Systematics of Subfamily Ictiobinae) and EF 0431259 (Collaborative Cypriniformes Tree of Life) to H.L.B. We thank Mark Clements (Harvard University Herbaria) for his contributions to both of these projects. We thank Rick Mayden, Rob Wood, and Kevin Tang (St. Louis University), Andrew Simon (University of Minnesota), Phil Harris (University of Alabama), Wayne Starnes and Gabriela Hoag (North Carolina State Museum), Tom Turner and Lex Snyder (Museum of Southwestern Biology), Doug Markle (Oregon State University), Bob Jenkins (Roanoke College), Guenter Schuster (Eastern Kentucky University) and Mollie Cashner (Tulane University) for help securing tissues of many of the cypriniform fishes and outgroups used in this study. We thank Donnielle Minor (Dillard University) for assistance with laboratory work. Lastly, we thank two anonymous reviewers for comments and editorial suggestions that improved the manuscript.

\section{References and Notes}

1. Ohno, S. Evolution by Gene Duplication; Springer-Verlag: New York, NY, USA, 1970.

2. Lynch, M.; Conery, J.S. The evolutionary fate and consequences of duplicate genes. Science 2000, 290, 1151-1155.

3. Vogel, G. Doubled genes may explain fish diversity. Science 1998, 281, 1119-1121.

4. Meyer, A.; Schartl, M. Gene and genome duplications in vertebrates: The one-to-four (-to-eight in fish) rule and the evolution of novel gene functions. Curr. Opin. Cell Biol. 1999, 1, 699-704.

5. Meyer, A.; van de Peer, Y. From $2 \mathrm{R}$ to $3 \mathrm{R}$ : Evidence for a fish-specific genome duplication (FSGD). Bioessays 2005, 27, 937-945.

6. Volff, J.N. Genome evolution and biodiversity in teleost fish. Heredity 2005, 94, 280-294.

7. Chen, T.T.; Marsh, A.; Shamblott, M.; Chan, K.-M.; Tang, Y.-L.; Cheng, C.M.; Yang, B.-Y. Structure and evolution of fish growth hormone and insulinlike growth factor genes. In Fish Physiology: Molecular Endocrinology of Fish; Sherwood, N.M., Hew, C.L., Eds.; Academic Press, Inc.: San Diego, CA, USA, 1994; Volume 13, pp. 179-209.

8. Yowe, D.L.; Epping, R.J. Cloning of the barramundi growth hormone-encoding gene: a comparative analysis of higher and lower vertebrate GH genes. Gene 1995, 162, 255-259.

9. Kawauchi, H.; Suzuki, K.; Yamazaki, T.; Moiryama, S.; Nozaki, M.; Yamaguchi, K.; Takahashi, A.; Youson, J.; Sower, S.A. Identification of growth hormone in the sea lamprey, an extant representative of a group of the most ancient vertebrates. Endocrinology 2002, 143, 4916-4921.

10. Yuri, T.; Kimball, R.T.; Braun, E.L.; Braun, M.J. Duplication of accelerated evolution and growth hormone gene in passerine birds. Mol. Biol. Evol. 2008, 25, 352-361.

11. Forsyth, I. A.; Wallis, M. Growth hormone and prolactin-Molecular and functional evolution. $J$. Mam. Gland Biol. Neoplasia 2002, 7, 291-312.

12. Rubin, D.A.; Dores, D.M. Cloning of a growth hormone from a primitive bony fish and its phylogenetic relationships. Gen. Comp. Endo. 1994, 95, 71-83.

13. Rubin, D.A.; Youson, J.H.; Marra, L.E.; Dores, D.M. Cloning of a gar (Lepisosteus osseus) GH cDNA: trends in actinopterygian GH structure. J. Mol. Endo. 1996, 16, 73-80. 
14. Schneider, J.F.; Myster, S.H.; Hackett, P.B.; Guise, K.S.; Faras, A.J. Molecular cloning and sequence analysis of the cDNA for northern pike (Esox lucius) growth hormone. Mol. Mar. Biol. Biotech. 1992, 1, 106-112.

15. Venkatesh, B.; Brenner, S. Genomic structure and sequence of the pufferfish (Fugu rubripes) growth hormone-encoding gene: A comparative analysis of teleost growth hormone genes. Gene 1997, 187, 211-215.

16. Clements, M.D.; Bart, H.L., Jr.; Hurley, D.L. Isolation and characterization of two distinct growth hormone cDNAs from the tetraploid smallmouth buffalofish (Ictiobus bubalus). Gen. Comp. Endo. 2004, 136, 411-418.

17. Bernardi, G.; D'Onofrio, G.; Caccio, S.; Bernardi, G. Molecular phylogeny of bony fishes, based on the amino acid sequence of the growth hormone. J. Mol. Evo. 1993, 37, 644-649.

18. Almuly, R.; Cavari, B.; Ferstman, H.; Kolodny, O.; Funkenstein, B. Genomic structure and sequence of the gilthead seabream (Sparus aurata) growth hormone-encoding gene: identification of minisatellite polymorphism in intron I. Genome 2000, 43, 836-845.

19. Rubin, D.A.; Dores, D.M. Obtaining a more resolute teleost growth hormone phylogeny by introduction of gaps in sequence alignment. Mol. Phylo. Evol. 1995, 4, 129-138.

20. Oakley, T.H.; Phillips, R.B. Phylogeny of salmonine fishes based on growth hormone introns: Atlantic (Salmo) and Pacific (Oncorhynchus) salmon are not sister taxa. Mol. Phylo. Evol. 1999, 11, 381-393.

21. Rajesh, R.; Majumdar, K.C. A comparative account of the structure of the growth hormone encoding gene and genetic interrelationship in six species of the genus Labeo. Fish Physiol. Biol. 2007, 33, 311-333.

22. Schlee, P.; Fuchs, H.; Blusch, J.; Werner, T.; Rotmann, O.; Stein, H. Genetic polymorphism in the intron of the growth hormone gene of the bleak. J. Fish Biol. 1996, 48, 1275-1277.

23. Yue, G.; Li, Y.; Orban, L. Characterization of microsatellites in the IGF-2 and GH genes of Asian seabass (Lates calcarifer). Mar. Biotech. 2001, 3, 1-3.

24. Mayden, R.L.; Chen, W.-J.; Bart, H.L., Jr.; Doosey, M.H.; Simons, A.M.; Tang, K.L.; Wood, R.M.; Agnew, M.K.; Yang, L.; Hirt, M.V.; Clements, M.D.; Saitoh, K.; Sado, T.; Miya, M.; Nishida, M. Reconstructing the phylogenetic relationships of the Earth's most diverse clade of freshwater fishes-Order Cypriniformes (Actinopterygii: Ostariophysi): A case study using multiple nuclear loci and the mitochondrial genome. Mol. Phylo. Evol. 2009, 51, 500-514.

25. Uyeno, T.; Smith, G.R. Tetraploid origin of the karyotype of catostomid fishes. Science 1972, $175,644-646$.

26. Chiou, C.-S.; Chen, H.-T.; Chang, W.-C. The complete nucleotide sequence of the growthhormone gene from the common carp (Cyprinus carpio). Biochim. Biophys. Acta 1990, 1087, 91-94.

27. Zhu, Z.; He, L.; Chen, T.T. Primary-structural and evolutionary analyses of the growth-hormone gene from grass carp (Ctenopharyngodon idellus). Eur. J. Biochem. 1992, 207, 643-648.

28. Noh, J.K.; Cho, K.N.; Nam, Y.K.; Kim, D.S.; Kim, C.G. Genomic organization and sequence of the mud loach (Misgurnus mizolepis) growth hormone gene: A comparative analysis of teleost growth hormone genes. Mol. Cells 1999, 9, 638-645. 
29. Deeds, E.J.; Shakhnavich, E.I. A structure-centric view of protein evolution, design, and adaptation. Adv. Enzymol. Relat. Areas Mol. Biol. 2007, 75, 133-191.

30. Sawada, Y. Phylogeny and zoogeography of the superfamily Cobitoidea (Cyprinoidei, Cypriniformes). Mem. Fac. Fish. Hokkaido Univ. 1982, 28, 65-223.

31. Siebert, D.J. Interrelationships among Families of the ORDER CYPRINIFORMES (Teleostei) Unpubl. Ph.D. Thesis, City University of New York: New York, NY, USA, 1987.

32. Harris, P.M.; Mayden, R.L. Phylogenetic relationships of major clades of Catostomidae (Teleostei: Cypriniformes) as inferred from mitochondrial SSU and LSU rDNA sequences. Mol. Phylo. Evol. 2001, 20, 225-237.

33. Doosey, M.H.; Bart, H.L., Jr.; Saitoh, K.; Miya, M. Phylogenetic relationships of catostomid fishes (Actinopterygii: Cypriniformes) based on mitochondrial ND4/ND5 gene sequences. Mol. Phylo. Evol. 2010, 54, 1028-1034.

34. Etherton, T.D.; Bauman, D.E. Biology of somatotropin in growth and lactation of domestic animals. Physiol. Rev. 1998, 78, 235-241.

35. Waters, M.J.; Shang, C.A.; Behnchen, S.N.; Tam, S.P.; Li, H.; Shen, B.; Lobie, P.E. Growth hormone as a cytokine. Clin. Exp. Pharmacol. Physiol. 1999, 26, 760-764.

36. Sanders, E.S.; Harvey, S. Growth hormone as an early embryonic growth and differentiation factor. Anat. Embryol. 2004, 209, 1-9.

37. Thompson, J.D.; Higgins, D.G.; Gibson, T.J. CLUSTAL W: Improving the sensitivity of progressive multiple sequence alignment through sequence weighting, position specific gap penalties and weight matrix choice. Nucleic Acids Res. 1994, 22, 4673-4680.

38. Hall, T.A. BioEdit: a user-friendly biological sequence alignment editor and analysis program for Windows 95/98/NT. Nucleic Acids Symp. 1999, 41, 95-98.

39. Stamatakis, A.; Hoover, P.; Rougemont, J. A rapid bootstrap algorithm for the RAxML web servers. Systemat. Biol. 2008, 57, 758-771.

40. Swofford, D.L. PAUP* Phylogenetic Analysis Using Parsimony (*and Other Methods), 4th ed. (4.0b10); Sinauer Associates: Sunderland, MA, USA, 2002.

41. Nei, M.; Gojobori, T. Simple methods for estimating the numbers of synonymous and nonsynonymous nucleotide substitutions. Mol. Biol. Evol. 1986, 3, 418-426.

42. Tamura, K.; Dudley, J.; Nei, M.; Kumar, S. MEGA4: Molecular evolutionary genetics analysis (MEGA) software version 4.0. Mol. Biol. Evol. 2007, 24, 1596-1599.

43. Nei, M.; Kumar, S. Molecular Evolution and Phylogenetics; Oxford University Press: New York, NY, USA, 2000.

(C) 2010 by the authors; licensee Molecular Diversity Preservation International, Basel, Switzerland. This article is an open-access article distributed under the terms and conditions of the Creative Commons Attribution license (http://creativecommons.org/licenses/by/3.0/). 